\title{
Paducah Gaseous Diffusion Plant Annual Site Environmental Report Summary for 1993
}

November 1994

This pamphlet contains summaries of the environmental programs at Paducah Gaseous Diffusion Plant, environmental monitoring and the results, and the impact of operations on the environment and the public for 1993. More detailed information on the material summarized in this pamphlet is available in the Paducah Gaseous Diffusion Plant Annual Site Environmental Report for 1993. The data used to compile the annual site environmental report and this summary pamphlet are published in the Paducah Gaseous Diffusion Plant Annual Site Environmental Data for 1993, which is a collection of tables containing effluent monitoring, environmental surveillance, and dose calculation data for 1993.

To obtain copies of any of these documents, contact

Vicki W. Jones

Environmental Compliance Coordinator

Paducah Site

761 Veterans Avenue

Kevil, KY 42053

Telephone: 502-462-3858

Prepared by Environmental, Safety, and Health Compliance and Environmental Management staffs, Martin Marietta Energy Systems, Inc., P.O. Box 2008, Oak Ridge, Tennessee 37831-6285, and the Environmental Management Associate Division, Paducah Gaseous Diffusion Plant, Martin Marietta, Energy Systems, Inc., P.O. Box 1410, Paducah, Kentucky 42001, for the U.S. Department of Energy, under contract No.

DE-AC05-84OR21400, and Martin Marietta Utility Services, Inc., for the United States Enrichment Corporation, under contract No. DE-AC05-76OR00001.

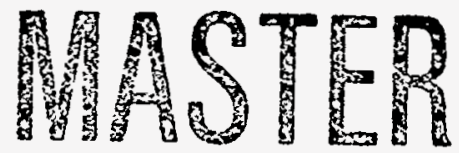




\section{CONTENTS}

About Paducah Gaseous Diffusion Plant $\ldots \ldots \ldots \ldots \ldots \ldots$

Environmental Programs at Paducah $\ldots \ldots \ldots \ldots \ldots \ldots \ldots$

Environmental Compliance $\ldots \ldots \ldots \ldots \ldots \ldots$

Environmental Monitoring $\ldots \ldots \ldots \ldots \ldots \ldots \ldots$

Nonradiological Monitoring and Surveillance $\ldots \ldots \ldots \ldots \ldots$

Radiological Monitoring and Surveillance . . . . . . . . . . . . . 13

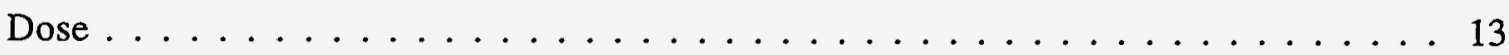

Pathways of Radiation . . . . . . . . . . . . . . . 15

Calculating Dose ........................ 16

1993 Radiological Monitoring Results . . . . . . . . . . . . . . . . . . . . 17

Radiation Dose to the Public from Paducah Plant Operations . . . . . . . . . . . . . . 19

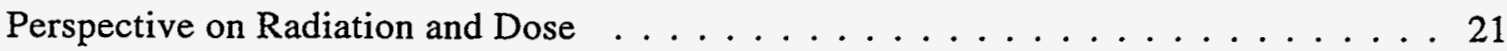




\section{DISCLAIMER}

This report was prepared as an account of work sponsored by an agency of the United States Government. Neither the United States Government nor any agency thereof, nor any of their employees, make any warranty, express or implied, or assumes any legal liability or responsibility for the accuracy, completeness, or usefulness of any information, apparatus, product, or process disclosed, or represents that its use would not infringe privately owned rights. Reference herein to any specific commercial product, process, or service by trade name, trademark, manufacturer, or otherwise does not necessarily constitute or imply its endorsement, recommendation, or favoring by the United States Government or any agency thereof. The views and opinions of authors expressed herein do not necessarily state or reflect those of the United States Government or any agency thereof. 


\section{DISCLAIMER}

Portions of this document may be illegible in electronic image products. Images are produced from the best available original document. 


\section{ABOUT PADUCAH GASEOUS DIFFUSION PLANT}

The Paducah plant (Figure 1) is one of two government-owned, contractor-operated uranium enrichment facilities within the U.S. Department of Energy (DOE) complex. As of July 1, 1993, responsibility for environmental compliance was split between DOE, as site owner and operator of waste management and environmental remediation projects, and the United States Enrichment Corporation (USEC), a government-owned corporation formed by the Energy Policy Act of 1992 to take over the nation's uranium enrichment business. Martin Marietta Energy Systems, Inc., manages and operates the Paducah site for DOE. Martin Marietta Utility Services, Inc., provides operating and maintenance services for USEC. The Nuclear Regulatory Commission is scheduled to assume direct oversight of USEC operations in October 1995. Until then, DOE is providing oversight of nuclear safety and safeguards and security.

ORNL PHOTO $7322-94$

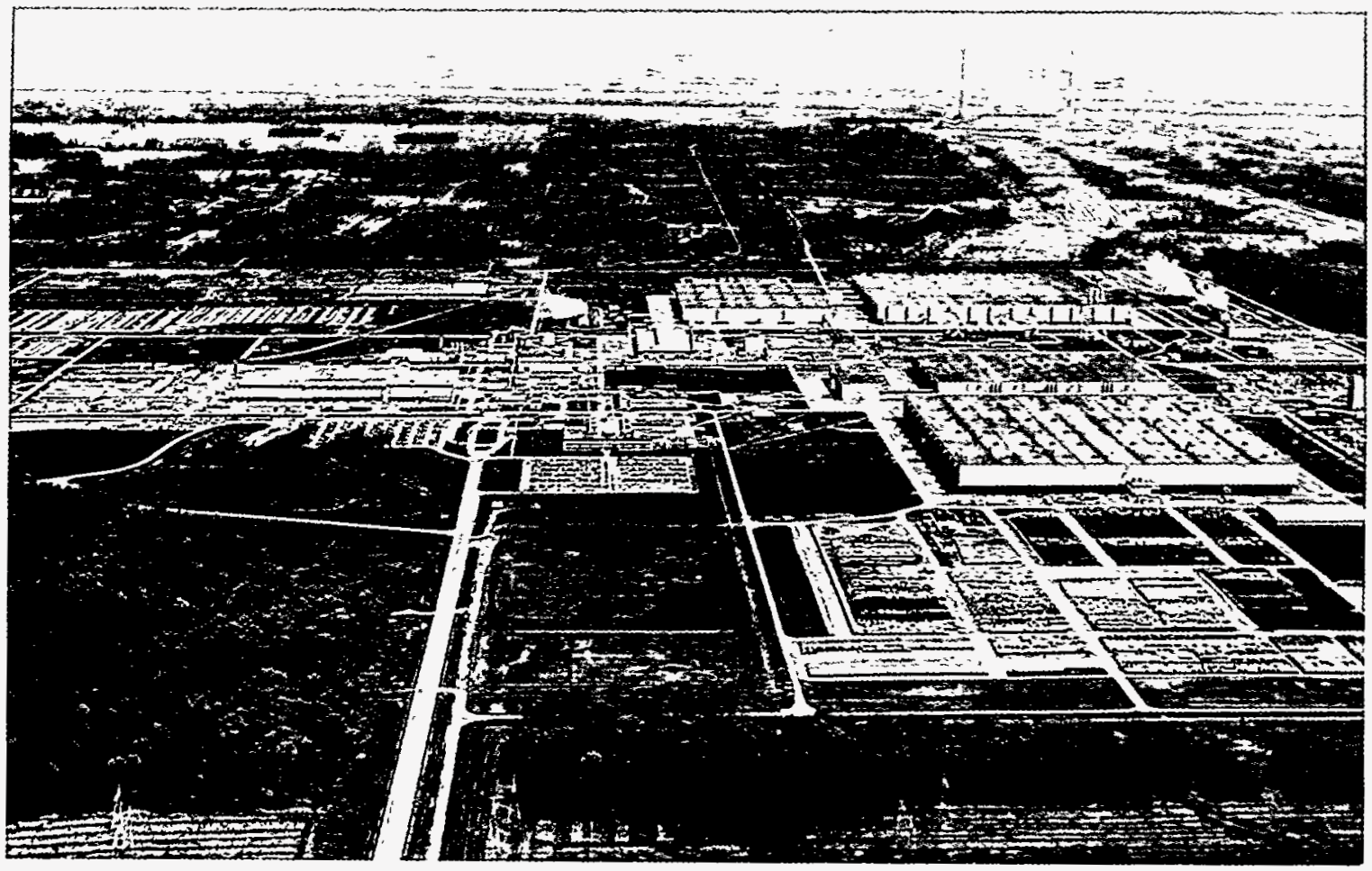

Figure 1. Paducah Gaseous Diffusion Plant is one of two DOE-owned uranium enrichment facilities.

The Paducah facility is located in McCracken County, Kentucky, about 10 miles west of Paducah and 3 miles south of the Ohio River. About 750 acres are contained within the security fence, where the buildings containing the uranium enrichment process equipment and the support facilities are located (Figure 2). The population within 50 miles of the plant is about 300,500 .

Before World War II, the area now occupied by the Paducah plant was used for agricultural purposes. Numerous small farms produced various grain crops and provided pasture for livestock. Early in the war, a 16,126-acre tract was assembled for construction of the Kentucky Ordnance Works, which was subsequently operated by the Atlas Powder Company until the end of the war when it was turned over to the Federal Farm Mortgage Corporation and then to the General Services Administration. 
ORNL-DWG 94M-9704R

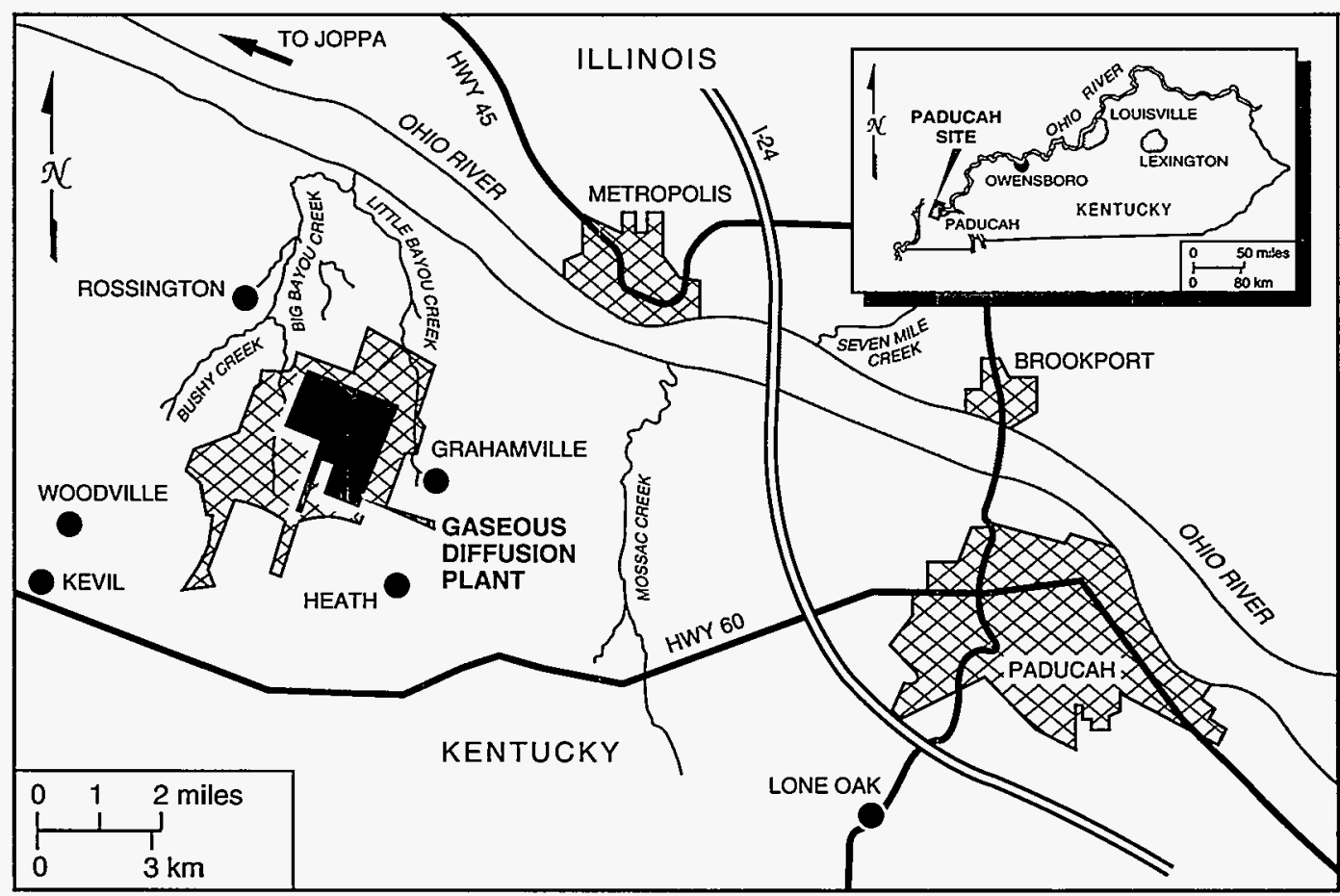

Figure 2. Location of the Paducah site within the state of Kentucky and in relation to the geographic region.

In 1950, the Department of Defense and DOE's predecessor, the Atomic Energy Commission (AEC), began efforts to expand fissionable material production capacity. As part of this effort, the National Security Resources Board was instructed to designate power areas within the strategically safe area of the United States. Eight government-owned sites were initially selected as candidate areas, one of which was the Kentucky Ordnance Works site. In October 1950, as a result of joint recommendations from the Department of Defense, Department of State, and the AEC, President Truman directed the AEC to further expand production of atomic weapons. One part of this expansion program was the provision for a new gaseous diffusion plant. In October 1950, the AEC approved the Paducah site for uranium enrichment operations and formally requested the Department of the Army to transfer the site from the General Services Administration to the AEC.

Construction of the Paducah plant was completed in 1954, although production began in 1952. The plant's mission, uranium enrichment, has continued unchanged, and the original facilities (with substantial upgrading and refurbishment) are still in operation. Of the 7566 acres acquired by the AEC, 1361 were subsequently transferred to the Tennessee Valley Authority (Shawnee Steam Plant site), and 2781 acres were conveyed to the commonwealth of Kentucky for use in wildlife conservation and recreational purposes. Thus, the site now occupies 3424 acres. 


\section{ENVIRONMENTAL PROGRAMS AT PADUCAH}

Environmentally related programs at Paducah include those run by the Environmental Restoration and Waste Management Public Affairs Department and a Waste Minimization/Pollution Prevention Program. The purpose of the Public Affairs programs is to inform and educate the public about site efforts to protect and restore the local environment. Activities include public briefings, publications, and special events and are designed to solicit input from the public and involve them in decision making. The goal of the Waste Minimization/Pollution Prevention Program is to minimize the generation of wastes at the plant.

\section{Public Affairs Programs}

\section{Neighborhood Council}

The Paducah Neighborhood Council is made up of eight individuals who live near the plant. During 1993, the council was briefed on a variety of environmental restoration projects and provided meaningful input on these and other issues.

\section{Information Bulletins, Fact Sheets, and Public Briefings}

During 1993, the Public Affairs Department produced two general information bulletins on environmental issues and cleanup activities at the plant and mailed the bulletins to about 4,000 people and agencies in the region. The department also published fact sheets on agreements between Paducah and regulatory agencies, radiological terms, and other topics. On April 6,1993, a public briefing was held on a variety of environmental issues; about 50 members of the public attended. In addition, Public Affairs personnel, along with DOE and MMES officials, regularly visit plant neighbors to hear their concerns and answer their questions firsthand.

\section{Environmental Advisory Committee}

The Paducah Gaseous Diffusion Plant Environmental Advisory Committee, chartered in 1986 as part of a program to solicit expert and general public input on environmental issues at MMES facilities, includes scientists, academics, business people, and members of the general public. In 1993 the committee was briefed on a wide range of issues; it provided meaningful input on several projects and has been instrumental in decision making.

\section{School Participation}

The role of the Public Affairs Department in planning and taking part in annual Earth Day activities has grown over the years to include a partnership with Heath Middle School and the West Kentucky Wildlife Management Area. A variety of environmental educational programs are planned each year in the Wildlife Management Area and on DOE property. The event has been very successful and grows larger each year. In addition to Earth Day activities, Public Affairs arranged for projects with area schools, such as providing judges for science fairs and providing speakers on environmental topics. 


\section{Waste Mlinimization/Pollution Prevention Program}

The Waste Minimization/Pollution Prevention Program was started in 1987 and provides guidance and objectives for minimizing solid waste generation and discharges to the environment. Conserving natural resources and protecting the environment is DOE policy.

\section{Program Implementation}

In conjunction with Environmental Policy departments and the Waste Management Operations Department, the Waste Minimization Program manager identifies wastes that are high-priority candidates for minimization or reduction.

Projects are divided into two categories: those that can be accomplished with existing resources and those that require additional resources. A project team is established for each individual project and is chaired by the Waste Minimization Program manager. Large projects may take the form of a formal Total Quality Management project when significant funding may be required or when the project could result in significant changes in facilities, systems, or operational procedures. Following completion of the Total Quality Management or pilot project, the project team makes a recommendation to the Waste Minimization Program manager and to plant management concerning the project. Management then decides whether to fully implement the project.

\section{ENVIRONMENTAL COMPLIANCE}

The U.S. Environmental Protection Agency (USEPA) and the Kentucky Department for Environmental Protection are the principal agencies responsible for regulating environmental compliance at Paducah. These agencies issue permits, review compliance reports, participate in joint monitoring programs, inspect facilities and operations, and oversee compliance with applicable regulations. Paducah must comply with numerous federal and state laws, a few of which follow.

Clean Air Act

Clean Water Act

Comprehensive Environmental Response, Compensation, and Liability Act

DOE/Kentucky Agreement-In-Principle

Endangered Species Act
Farmland Protection Policy Act National Environmental Policy Act National Historic Preservation Act Resource Conservation and Recovery Act Safe Drinking Water Act Toxic Substances Control Act

To ensure that compliance with environmental laws is maintained, numerous oversight activities are performed by internal and external organizations. These activities include audits, appraisals, inspections, and surveillances. The basic goal of these oversight activities is to evaluate whether the environmental laws are being met and to improve environmental operations. During 1993, 17 audits, appraisals, inspections, or surveillances were conducted of the Paducah environmental programs. 


\section{ENVIRONMENTAL MONITORING}

\section{Basis for Environmental Monitoring}

The operation of most industrial facilities involves processing and handling of materials that if released to the environment could cause harm. As a result of routine operations at Paducah, radioactive contaminants and nonradioactive contaminants, such as chemicals and metals, are released to the environment. Paducah has an extensive environmental monitoring program to determine the effect of operations on the environment and public health. The basis for judging releases acceptable includes scientific studies on the effects of radiation and hazardous materials as well as allowable levels set by federal and state regulatory agencies.

The environmental monitoring program at Paducah includes effluent monitoring and environmental surveillance. Effluent monitoring is measurement of releases as they occur. Contaminants are released through either airborne emissions or liquids discharged from the plant. These releases occur as part of normal site operations, such as cooling water discharged from the uranium enrichment cascade operations or airborne releases from ventilation systems. In the event of system failure, this monitoring provides timely warning so that corrective action can be taken before releases reach an unsafe level. Environmental surveillance tracks the dispersion of materials into the environment after they have been released. This involves the collection of samples from various media, such as water, soil, vegetation, and food crops, and the analysis of these samples for certain radionuclides, chemicals, and metals. Deciding what to monitor and how to monitor it is based on

- environmental regulations,

- measurement capabilities,

- analyses of potential pathways for contaminants to reach and affect the public, and

- public concerns.

\section{Monitoring versus surveillance}

Per DOE Order 5400.5, Radiation Protection of the Public and the Environment.

Effluent monitoring is the collection and analysis of samples or measurements of liquid and gaseous effluents for purposes of characterizing and quantifying contaminants, assessing radiation exposure to members of the public, and demonstrating compliance with applicable standards.

Environmental surveillance is the collection and analysis of samples of air, water, soil, foodstuffs, biota, and other media from DOE sites and their environs and the measurement of external radiation for purposes of demonstrating compliance with applicable standards, assessing radiation exposures to members of the public, and assessing effects, if any, on the local environment.

Monitoring occurs at the point of discharge, such as an air stack or drainage pipe, whereas surveillance involves looking for contaminants already present in the environment. 
Because Paducah's primary mission is processing radiological materials, much of the environmental monitoring effort is directed toward radioactive materials. Radioactive materials are regulated at the point of discharge and are monitored before they disperse into the surrounding environment. However, most of the radionuclides managed at Paducah are also naturally present in the environment, and the amounts released are so small that it becomes difficult to distinguish the releases from the natural environment. For this reason, mathematical models are used to estimate how and in what quantities radionuclides are carried and dispersed into the environment.

These models are also used to help optimize the effectiveness of the existing radiological monitoring program. For example, predictions based on models can be helpful in choosing the best locations for measuring devices and in identifying pathways for contaminants to travel and the most important contaminants to monitor for. Modeling contributes to the best use of resources available for sampling and analysis and helps verify that sampling is being performed adequately.

\section{Environmental Regulations}

Numerous state and federal regulations, such as the Clean Air Act and Clean Water Act, limit the amount of radioactive and nonradioactive contaminants the Paducah site is allowed to discharge and are drivers for the monitoring conducted at Paducah. In addition to these regulations are DOE guidelines, contained in DOE orders. Compliance with these regulations is overseen by several agencies, including the USEPA. Paducah is accountable to state and federal regulators and must supply valid data on releases.

Airborne discharges are regulated by the Kentucky Division for Air Quality and the USEPA. Airborne discharges of radionuclides are regulated primarily by the USEPA under the Clean Air Act and the National Emission Standards for Hazardous Air Pollutants and by DOE orders. Nonradiological emissions are regulated primarily by the Kentucky Division for Air Quality.

Nonradiological liquid discharges are regulated by the Kentucky Division of Water through the Kentucky Pollutant Discharge Elimination System Wastewater Discharge Permitting Program. Liquid discharges of radionuclides are regulated by DOE orders 5400.1, General Environmental Protection Program, and 5400.5, Radiation Protection of the Public and the Environment.

\section{Quality Assurance and Quality Control}

When monitoring releases and measuring radiation in the environment, the reliability of the data is of the utmost importance. To ensure that the monitoring and measurement results are accurate, Paducah has a quality assurance and quality control program based on guidelines from the USEPA, the American Society for Testing and Materials, and other federal and state agencies. The Environmental Monitoring Department at Paducah administers internal quality control programs to ensure reliability of the data on a day-to-day basis (Figure 3). 


\section{NONRADIOLOGICAL MONITORING AND SURVEILLANCE}

The nonradiological monitoring program is designed to ensure that atmospheric and liquid releases are safe and within regulatory limits. Based on regulatory guides, the program focuses on monitoring of airborne and liquid releases and surveillance of the environment, which includes air, surface water, drinking water, groundwater, sediment (from streambeds), soil, vegetation, fish, and wildlife.

\section{Monitoring}

Nonradiological emissions of concern at Paducah include potentially harmful chemicals, pollutants, and ozone-depleting compounds. Facilities and operations that release such emissions include the coal- and oil-fired boilers, the paint shop, fuel dispensing, and the gaseous diffusion cascade and its coolant system. Emissions in 1993 were all within applicable limits.

Monitoring of nonradiological plant-site liquid effluents is conducted at 18 outfalls (locations where liquids are discharged) that are regulated by the Kentucky Pollutant Discharge Elimination System. No exceedences of the permit limits occurred in 1993.

\section{Surface Water Sampling}

Surface water sampling is conducted from a weekly to an annual basis, depending on the location. Results for 1993 were all within applicable limits.

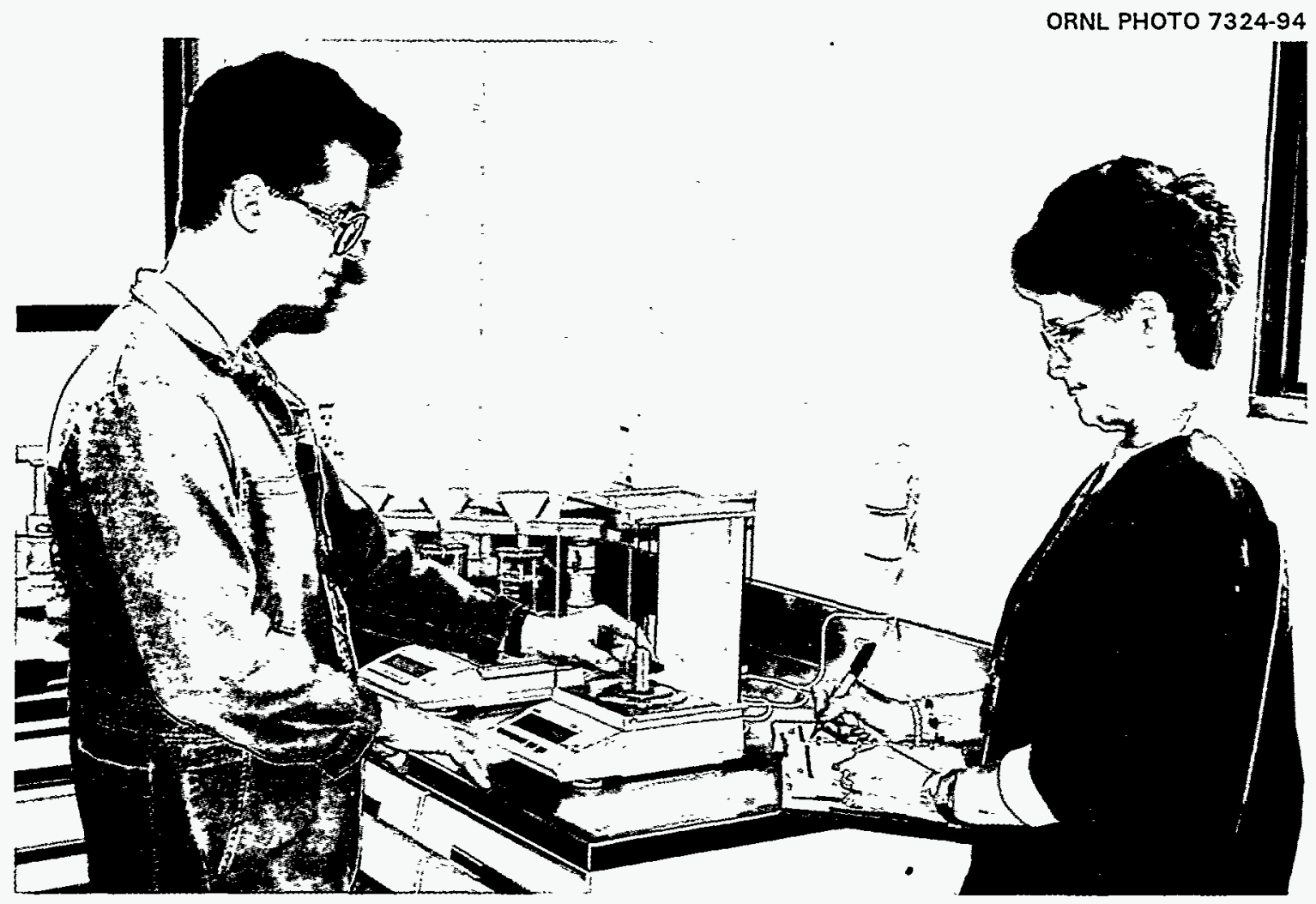

Figure 3. Lab technicians at Paducah follow quality control procedures to ensure the reliability of environmental monitoring data on a day-to-day basis. 


\section{Groundwater Surveillance}

The purpose of groundwater monitoring is to identify any groundwater contamination and determine the movement of groundwater near the Paducah plant so that the movement of any contaminants can be tracked. Monitoring wells are used extensively to assess the effect of Paducah operations on groundwater quality, generally to determine the effect of a specific site on nearby groundwater quality (see Figures 4 and 5). Sampling is conducted at over 200 monitoring wells, residential wells, and wells that belong to the Tennessee Valley Authority.

Groundwater aquifers are one of the primary pathways by which potentially hazardous substances can enter the environment. Aquifers are sections of underground material (such as earth, rock, or. sand) that transmit water easily. Substances within the soil may be dissolved in rainwater, which moves them downward into the groundwater. The water then flows toward a discharge point. Groundwater systems of most interest to hydrogeologists at Paducah are the regional gravel aquifer (RGA) and the upper continental recharge system (UCRS) because the RGA is the primary aquifer used locally by private residences north of the plant and groundwater within the UCRS flows predominately downward, into the RGA.

Nonradiological groundwater monitoring focuses primarily on trichloroethylene (TCE), a degreasing agent used by many industries until its harmful environmental effects were discovered. TCE is a dense nonaqueous phase liquid (DNAPL), that is, a liquid with a density greater than water. DNAPLs are extremely difficult to remove. In fact, technology does not yet exist to remove them from aquifers; hence, DNAPLs are a continuing source of groundwater contamination. The USEPA regulates the maximum contaminant level in groundwater for TCE (5 micrograms per liter). Although other chemicals are monitored, TCE appears to be the only nonradiological contaminant threatening the RGA. Four TCE plumes have been identified, two on-site and two off-site (see Figure 6).

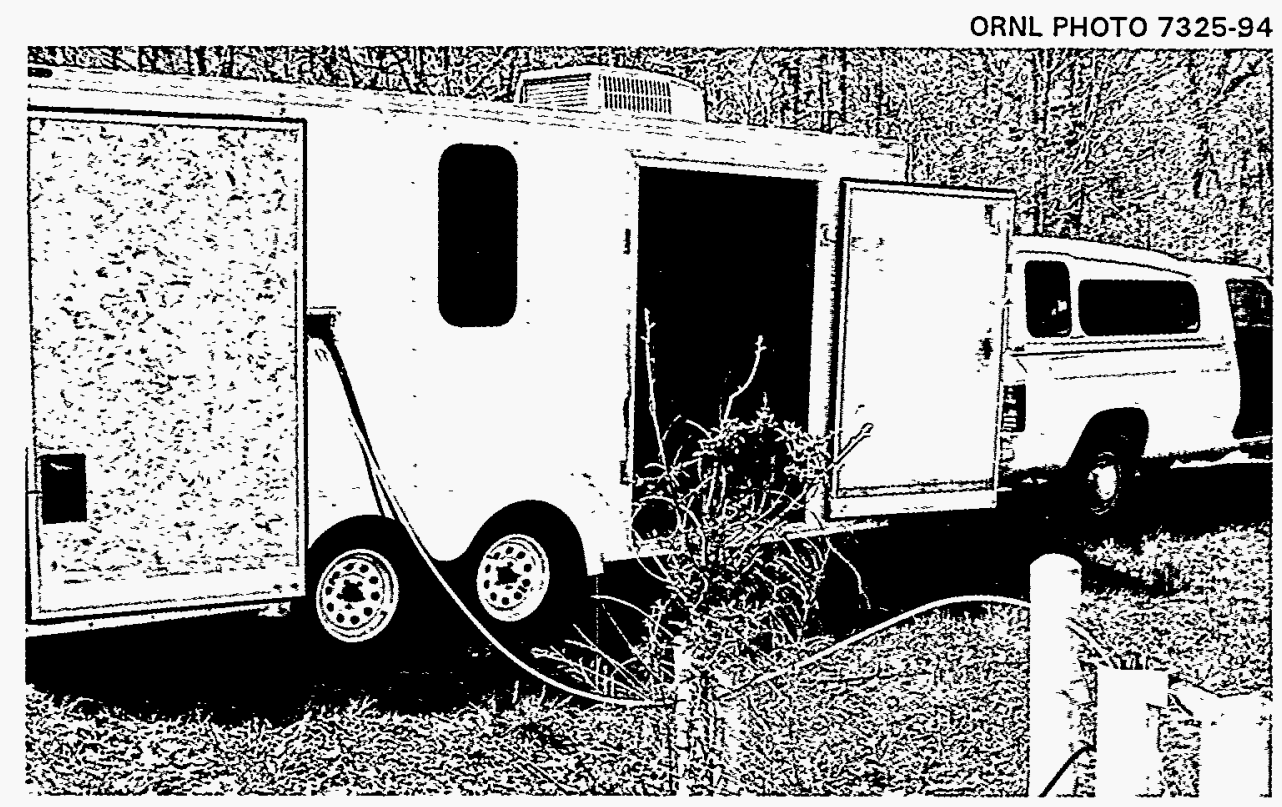

Figure 4. Mobile laboratory used to conduct groundwater well sampling. 


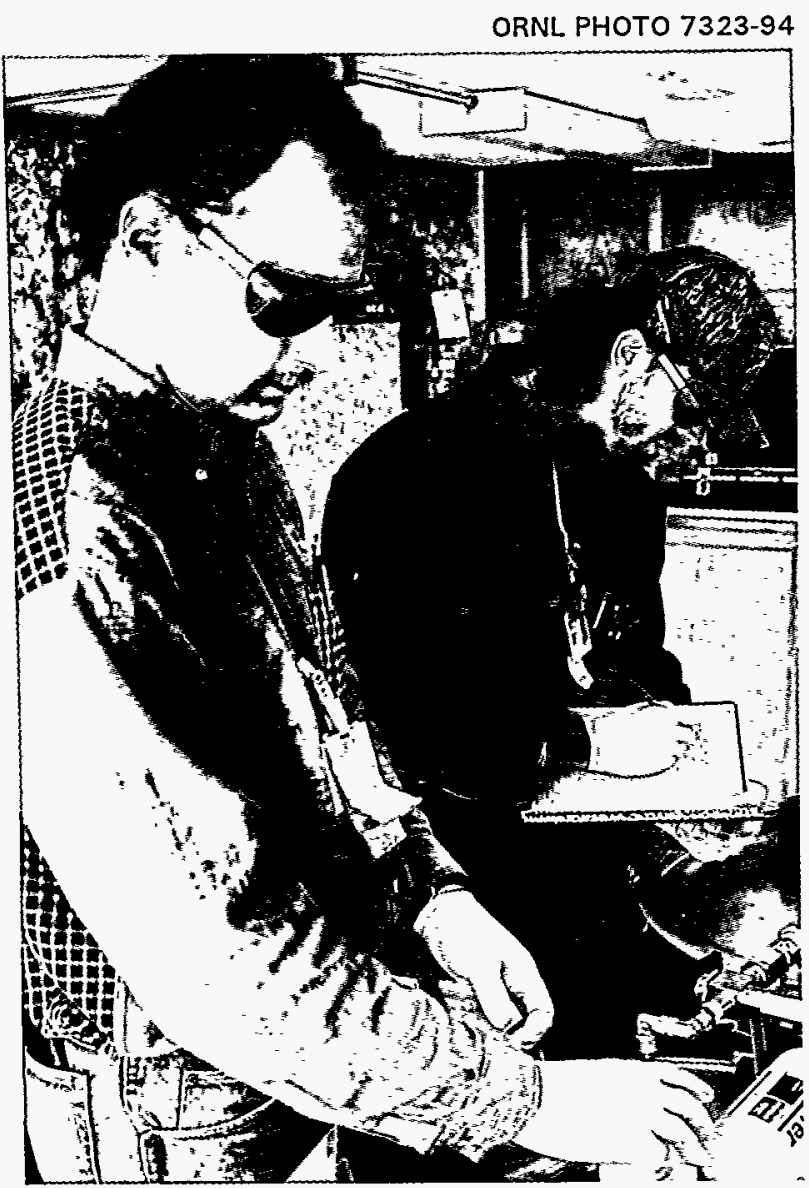

Figure 5. Inside the mobile laboratory, technicians label samples and keep extensive records of all well monitoring activities. The samples are then transferred to the Martin Marietta Utility Services plant laboratory for analysis.

Figure 6. Trichloroethylene (TCE) and technetium-99 $\left({ }^{99} \mathrm{TC}\right)$ groundwater plumes on and near the Paducah site.

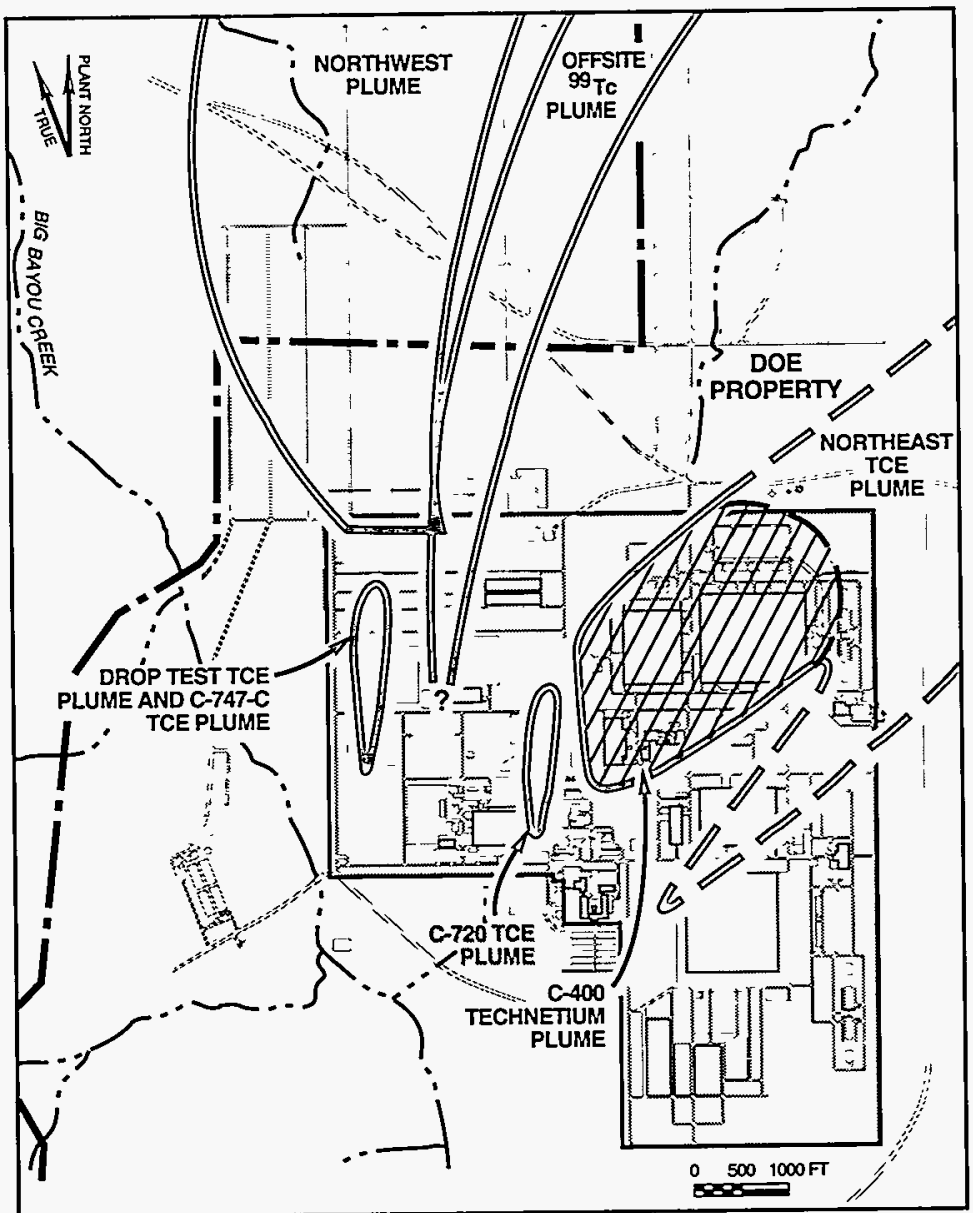




\section{Soil and Sediment Sampling}

Soil is sampled to determine if any airborne pollutants are accumulating in the soil. Although sampling is designed to minimize the differences among soils collected from different locations, the significance of individual units of data is small; data must be collected over many years to determine any significant changes in soil quality: Samples are analyzed for polychlorinated biphenyls (PCBs) and 35 metals. No detectable concentrations of PCBs were found in any of the samples collected in 1993. In some samples, concentrations of four metals were higher than in reference location samples. (A reference, or background, sample is one taken from an area not affected by Paducah operations.) Lead levels in all locations except one were higher than they have been in the past; however, levels were higher in background samples also. This may be attributed to changes in analytical practices; however, further investigation is ongoing.

Sediment sampling (from stream beds) also focuses on monitoring for PCBs and 35 metals. Concentrations of arsenic higher than in reference locations were detected at one location. Lead levels in all locations were higher this year and last year in both site and background locations than they have been in the past. This may be attributed to changes in analytical practices, but further investigation is ongoing. PCBs were detected at one location 2.9 times higher than 1992 levels. This result confirms past studies in which PCBs were detected and signs were posted at Little Bayou Creek to make the public aware of PCB contamination. PCB levels are still being investigated.

\section{Vegetation Sampling}

Vegetation (grass) samples are collected at 18 locations every three months. The primary objective of vegetation sampling is to determine the total fluorides that have accumulated in foliage. All samples were within acceptable limits for 1993.

\section{Fish and Wildlife Sampling}

As a result of sporadic positive lead results obtained from deer sampling in 1992, DOE, the Kentucky Department of Fish and Wildlife, and the Corps of Engineers conducted special testing in the Western Kentucky Wildlife Management Area. Although there is no evidence that DOE operations caused this problem, in compliance with DOE orders, DOE established a sampling plan designed to indicate contamination in the Wildlife Area's three most commonly used resources: deer, fish, and rabbits.

In August 1993, liver and muscle samples from eight deer were analyzed for metals and PCBs. Fat samples were also analyzed for PCBs. The liver, muscle, and fat tissue are evaluated for risks if analyses reveal detectable levels above reference deer because these types of tissues are considered consumable by hunters. Because all PCB concentrations were below the reporting limits, no evaluation was made of potential PCB intake. Other elements (molybdenum, strontium, selenium, and silver) were seen only in reservation deer.

Fish sampling was also conducted in 1993. Results revealed certain mercury concentrations higher than the U.S. Food and Drug Administration action level of $1 \mathrm{ppm}$. Resampling confirmed these results. No known pathway exists for Paducah contaminants to enter the southern ponds or the north pond at the Wildlife Area where sampling was conducted. The only direct link noted is rubble from Paducah that is used to build levees at some of the ponds. Nevertheless, signs were posted at various sampled ponds to notify the public that mercury had been found in some of the bass analyzed. 


\section{RADIOLOGICAL MONITORING AND SURVEILLANCE}

As stated earlier, because the primary mission of Paducah is processing radioactive materials, much of the environmental monitoring effort is directed toward radioactive materials. To determine the possible effect of radiation on the environment and people, radiation must be measured. To understand how radiation is measured, it's necessary to understand what radiation is.

Radiation and How It's Measured

All matter is made up of extremely small particles called atoms. Atoms are bundles of even smaller particles called protons, neutrons, and electrons. When an atom has the right combination of protons and neutrons, it is stable, or nonradioactive. Atoms that don't have the right combination break apart, or decay, in an attempt to become stable. When an unstable atom decays, it releases energy as particles and rays; this released energy is called radiation.

\section{Activity}

When radiation is measured, what is actually being measured is the rate of radioactive decay, or activity. Because activity varies among radioisotopes, one gram of one radioactive substance may contain the same amount of activity as several tons of another substance. Activity is expressed in curies.

\section{DOSE}

\section{Absorbed Dose}

The total amount of energy absorbed per unit mass as a result of exposure to radiation is expressed in rads. The health effects of radiation are proportional to the absorbed dose. However, the proportion is different for different types of radiation. Consequently, limits for radiation exposure are normally expressed as dose equivalents rather than absorbed dose.

\section{Dose Equivalent}

The potential biological damage caused by exposure to and absorption of radiation is expressed in rems (rem stands for roentgen equivalent man). One rem of one type of radiation has the same total damaging effect as any other type of radiation. The dose equivalent is equal to the absorbed dose from each type of radiation multiplied by a "quality factor." The quality factors have been set by international organizations so that an equal number of rems means an equal effect on health regardless of the type of radiation involved. Because a rem represents a fairly large dose, the millirem (mrem), 1/1,000 of a rem, is usually used when referring to the small potential doses from Paducah operations. 


\section{Committed Dose Equivalent}

Normally, the largest part of a person's radiation dose is from radioactive material that has been swallowed or inhaled. This material will continue to expose the person until it passes back out of the body, which may take longer than a single year. Therefore, the committed dose equivalent, expressed in rems, is the total dose equivalent that a person is expected to receive from radioactive material that was swallowed or inhaled during a specified period.

\section{Effective Dose Equivalent}

When a person swallows or inhales radioactive materials, each organ can receive different, often very different, radiation exposures. Therefore, the effective dose equivalent (EDE), expressed in rems, is an average of the committed dose equivalents to eleven major organs plus the dose equivalent caused by radiation from outside the body. EDE is used to express dose in terms of the potential health impact. Use of the EDE allows dose from different types of radiation and doses to different parts of the body to be expressed on the same basis. EDE is expressed in mrems.

\section{Units of Radiation Measure}

Radiation measurements in this pamphlet are expressed in the U.S. Customary System. The following information is provided for those who want to convert the measurements to the metric system.

\begin{tabular}{lll} 
U.S. Customary System & Metric System & Conversion \\
\hline $\begin{array}{l}\text { Activity } \\
\text { curie (Ci) }\end{array}$ & becquerel $(\mathrm{Bq})$ & $1 \mathrm{Ci}=3.7 \times 10^{10} \mathrm{~Bq}$ \\
$\begin{array}{l}\text { Absorbed dose } \\
\text { rad (radiation absorbed dose) }\end{array}$ & gray (Gy) & $1 \mathrm{rad}=0.01 \mathrm{~Gy}$ \\
$\begin{array}{l}\text { Dose equivalent } \\
\text { rem (roentgen equivalent man) }\end{array}$ & sievert (Sv) & $1 \mathrm{rem}=0.01 \mathrm{~Sv}$
\end{tabular}




\section{PATHWAYS OF RADIATION}

Radiation and radioactive material in the environment can reach people through many routes, or pathways (see Figure 7). For example, radioactive material in the air could fall on a pasture. The grass could then be eaten by cows, and the radioactive material on the grass would show up in the cow's milk. Thus, people drinking the milk would be exposed to this radiation. People also could simply inhale the radioactive material while it is still in the air. When radioactive materials occur in water, fish could absorb the materials and people who ate the fish would be exposed. People swimming in the water would also be exposed.

Although radioactivity is not affected by chemistry, the behavior of a radioactive substance in the body is. Consequently, a curie of two different radioactive substances, or even of the same substance in different chemical forms or passing through different pathways, can cause very different committed dose equivalents.

At Paducah, essentially all of the radiation dose to the public is from radioactive forms of uranium and technetium. Of the two, 1 curie of uranium will cause committed dose equivalents 100 times greater than 1 curie of technetium if swallowed and 1,000 times greater if inhaled. Because of this, Paducah has always considered controlling uranium emissions far more important than controlling technetium emissions. 


\section{CALCULATING DOSE}

With modern technology, very small amounts of radionuclides can be detected in environmental samples. However, many of the radionuclides released from Paducah are at such low concentrations when dispersed into the environment that they cannot be measured by routine laboratory methods. Also, it is sometimes difficult to tell if a radionuclide in the environment comes from Paducah or from another source. These factors make it difficult to directly measure public exposure to radioactive materials released from the site. Therefore, mathematical models are used to estimate the concentrations of radionuclides present in the environment as a result of releases to air and water (see Figure 8).

Basically, all air and liquid discharges from Paducah are monitored. Beginning with these measurements and factoring in many other conditions (e.g., wind direction, flow rates, and, in some cases, actual measurements from environmental samples), estimated concentrations are calculated. These estimated concentrations are used to estimate doses from site releases.

When calculating maximum doses from releases to the air and water from Paducah operations, the concept of a hypothetical individual who receives the maximum exposure from all pathways is used. This maximally exposed individual:

- For air pathways, lives 6700 feet north of the plant site in the predominant wind direction.

- For liquid pathways, drinks 730 liters of water contaminated with technetium at the detection limit of 25 picocuries per liter. No known drinking water source near the plant contains detectable levels of radionuclides.

Paducah uses the concept of the maximally exposed individual when estimating its contribution to the dose to the off-site population to ensure that the estimate is the highest any one individual could have received as a result of site operations. In reality, however, no individual actually receives this high a dose from Paducah operations.

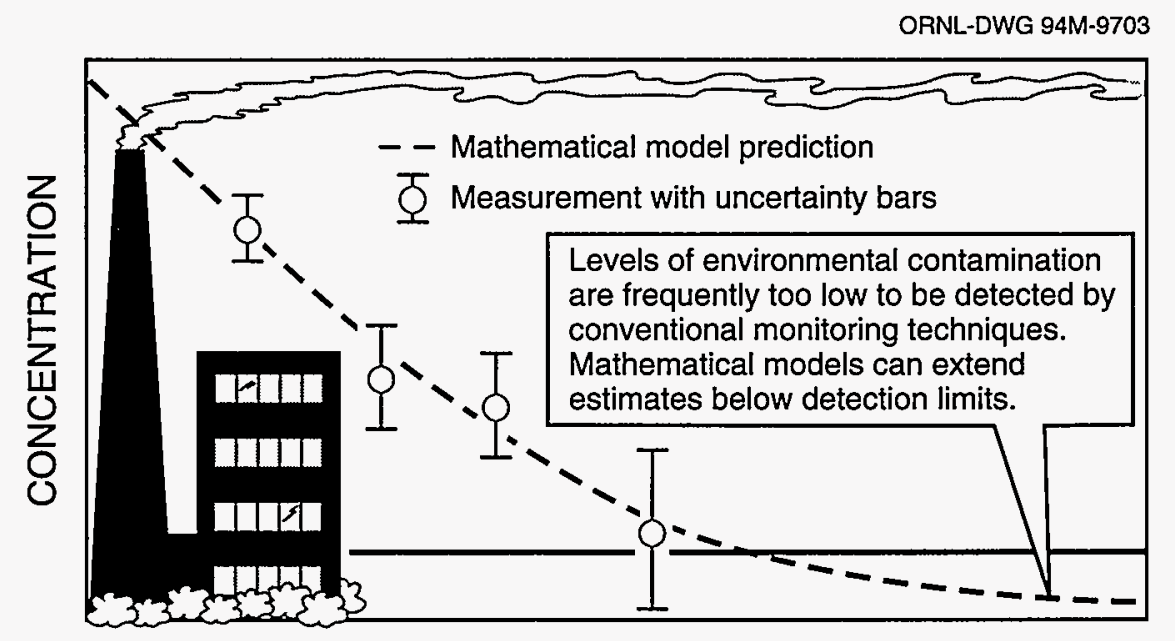

DISTANCE FROM POINT OF RELEASE

Figure 8. Radionuclide movement comparison-measured versus calculated. Once radionuclides are released, they often disperse into the environment in concentrations too small to measure using routine laboratory methods. Therefore, concentrations of these radionuclides must be determined using mathematical models designed to calculate how much of a radionuclide could be present in a given medium based on known physical parameters, such as meteorological conditions. 


\section{Uncertainty in Dose Calculations}

With calculated estimates of dose, as with any estimate, there is a level of uncertainty and many physical parameters must be taken into account. To calculate estimated doses to the public, Paducah uses standard radiation transport and dose models developed for the commercial nuclear industry and approved by the U.S. Nuclear Regulatory Commission. These computer-based models are regularly tested and verified to ensure that they provide proper and conservative (i.e., the maximum possible) estimates. They are also routinely updated to keep the uncertainty of the dose estimates as low as possible when site-specific conditions, such as weather patterns or river flow, change.

\section{RADIOLOGICAL MONITORING RESULTS}

The radiological monitoring and surveillance program at Paducah is designed to determine any effects routine and nonroutine operations may have on the site, the surroundings, and the local population. Effluents (air and water) are monitored for radionuclides known to be emitted or that have been present at the site. Radiological sampling is conducted for air, surface water, groundwater, soil and sediment, food crops, and wildlife. Direct radiation is also measured.

\section{Monitroring}

Airborne emissions were monitored for five radionuclides, and all were within acceptable limits set by DOE and federal and state standards. The average concentrations of radionuclides at all monitoring locations were small percentages (ranging from 1 to $16 \%$ ) of the allowable limits set by DOE. Measurements of radioactivity in the air on and around the Paducah reservation were well within applicable standards and were not significantly affected by Paducah releases.

\section{External Gamma Radiation Monitoring}

One of the potential exposure pathways for populations living in the Paducah vicinity is external radiation. Radiation is measured at 15 locations and converted to dose equivalent units (millirems). To estimate the maximum dose that could be received at these locations, calculations are made assuming that a person stays in the area continuously. Using this assumption, a person could receive a total measured dose of up to 44 mrem per year from background radiation plus plant contributions. This is within the expected background dose of 60 to 70 mrem per year estimated to be received by residents of Kentucky and Tennessee. Therefore, the net increase in the measured radiation dose from plant activities is zero.

\section{Suriace Water Sampling}

Elevated levels of radioactivity and of uranium and technetium were found at several downstream locations, indicating the concentrations are from the Paducah plant. However, all measurements were within the safe drinking water limits. 


\section{Groundwater Surveillance}

Radiological groundwater monitoring is conducted for specific radionuclides as well as general levels of radioactivity. Technetium- 99 is the only major threat to the regional gravel aquifer, a local groundwater area that provides drinking water to area residents. Three technetium-99 plumes have been identified. One plume is on the plant site; the other two are off-site, northwest of the plant (see Figure 6).

In July 1988, Paducah began providing bottled water to residents with affected wells. Since then, DOE has established a water policy that includes extending a municipal water line to the entire area that could be affected by groundwater contamination originating from the Paducah plant. All residents within the area, regardless of whether or not their wells were contaminated, were given the opportunity to receive municipal water at DOE expense when signing an agreement not use or dig wells on their property. Installation of the water line was completed in 1994.

\section{Soil and Sediment Sampling}

Soil is sampled to determine if airborne radionuclides are accumulating in the soil. Soil samples are taken annually at 10 locations on-site and at distances of up to 5 miles from the property boundary. The only radionuclide found was uranium, which was present in the same amounts as in previous years and in a form that occurs naturally.

Sediment samples were taken from six locations. Again, the only radionuclide found was uranium. Finding elevated levels of non-naturally occurring uranium downstream of the plant indicates that the uranium is from Paducah operations. This result confirms past studies in which uranium was detected and resulted in the posting of signs at Little Bayou Creek to inform the public that prolonged exposure could result in a dose above what would be received from background radiation.

\section{Food Crop Sampling}

Each year, food crops from local gardens are selected for analysis to monitor the effects of Paducah operations on local food crops (Figure 9 shows possible pathways for radioactive materials to reach food crops). Each sample was analyzed for seven radionuclides. The radionuclides detected are all known to be naturally occurring as well as being present at the plant. Data from 1992 and 1993 indicate that the levels of these radionuclides are slightly higher and are detected more often in the most prevalent wind directions, which indicates the effects of Paducah plant operations. However, the maximum dose that could be received from eating food crops with the highest level of uranium detected on a daily basis would be minimal (about 0.12 mrem per year).

\section{Wildlife Sampling}

To monitor the effects of Paducah operations on the ecology of the surrounding area, eight deer were harvested in the West Kentucky Wildlife Management Area. The data indicated no significant difference between the average concentrations of uranium isotopes in liver or muscle for reservation deer and for background deer taken from the Ballard County Wildlife Management Area. Plutonium-239 was found in one reservation deer; this has never been seen in the past, and future data will be watched for similar results. 
Detectable concentrations of uranium isotopes and strontium-90, a radionuclide present in the atmosphere from worldwide fallout, were found in most bone samples.

\section{RADIATION DOSE TO THE PUBLIC FROM PADUCAH PLANT OPERATIONS}

As stated earlier, most of the radioactive materials released from the Paducah site are present in such low concentrations in the environment that standard monitoring procedures can't detect them. Therefore, radiation doses to off-site populations are calculated with mathematical models. For 1993, the hypothetical maximally exposed individual could have received an estimated dose of 0.0023 mrem from site atmospheric releases and $2.1 \mathrm{mrem}$ from other possible pathways. This dose is a small fraction of the applicable federal dose standard of 100 mrem per year.

Knowledge of the demography and land use of the area surrounding the plant and identification of on-site radiation sources have indicated certain radionuclides and exposure pathways by which people can be exposed to radiation. In 1990, an assessment was conducted of the risk to public health from Paducah contaminants. This study identified four primary pathways that could contribute more than $1 \%$ to the total off-site dose to the public: exposure to direct radiation and ingestion of groundwater, sediment, and wildlife and food crops. To fully assess the potential dose to the public, a hypothetical group of extreme characteristics is used to estimate an upper limit to the dose of any actual group. In addition, the dose from all pathways from atmospheric releases is calculated.

Table 1 contains a summary of the annual dose from radiological contaminants that could be received by a member of the public living near the Paducah plant, assuming maximum exposure from all major pathways. The calculated maximum combined (internal and external) dose to an individual is 2.1 mrem per year. Again, this level is well below the DOE annual dose limit of 100 mrem per year to members of the public from operation of a DOE facility. Figure 10 shows how the potential dose of 2.1 mrem per year compares with the DOE limit and the average dose of background radiation to residents in the Paducah area. The major contributors to this dose are direct external radiation from and ingestion of sediment in or near the Little Bayou Creek bed. Signs have been posted in this area to notify the public of the elevated radiation levels.

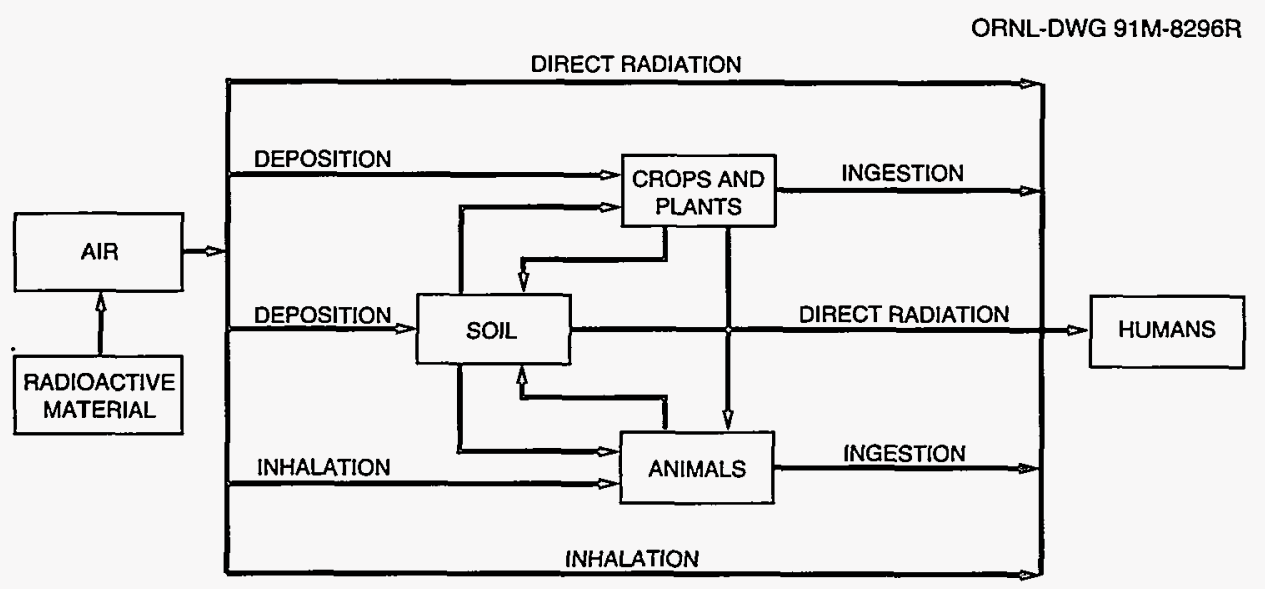

Figure 9. Possible pathways between radioactive material released to the atmosphere and individuals. 
Table 1. Summary of potential radiological dose for 1993 from the Paducah Gaseous Diffusion Plant

\begin{tabular}{lccc}
\hline \multicolumn{1}{c}{ Pathway } & $\begin{array}{c}\text { Dose } \\
\text { (mrem/year) }\end{array}$ & Portion of total & $\begin{array}{c}\text { Standard } \\
\text { (mrem/year) }\end{array}$ \\
\hline Ingestion of well water & 0.024 & $<0.01$ & $4^{b}$ \\
Ingestion of sediments & 1 & 0.64 & $10^{c}$ \\
Ingestion of food crops & 0.1 & 0.03 & $10^{c}$ \\
Ingestion of deer meat & $0^{d}$ & 0 & $10^{c}$ \\
Direct radiation-Little & 1 & 0.32 & $10^{c}$ \\
$\quad$ Bayou Creek & $0.0023^{e}$ & & $10^{c . f}$ \\
Atmospheric releases & 2 & & $100^{g}$ \\
Total annual dose above & 2 & & \\
background-all pathways & & & \\
\hline
\end{tabular}

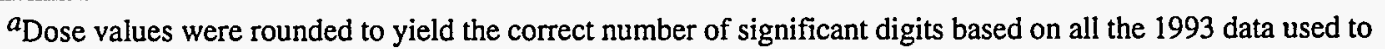
estimate the worst-case dose from all exposure pathways and from estimated significant figures in atmospheric releases per DOE/EH-0173T, Environmental Regulatory Guide for Radiological Effluent Monitoring and Environmental Surveillance.

bTitle 40, Code of Federal Regulations, Part 141 (40 CFR 141), "National Interim Primary Drinking Water Regulations." Under these regulations, persons consuming drinking water shall not receive an annual whole body dose of more than $4 \mathrm{mrem}(0.04 \mathrm{mSv})$. DOE Order 5400.5, Radiation Protection of the Public and the Environment, interprets this dose as effective dose equivalent of no more than $4 \mathrm{mrem}(0.04 \mathrm{mSv})$.

${ }^{c}$ DOE standard in DOE Order 5400.5.

${ }^{d}$ Calculated dose for reservation deer was less than the background, or reference, deer; therefore, the dose was assumed to be zero.

${ }^{e}$ Most all of the 50-year committed effective dose was received during 1993.

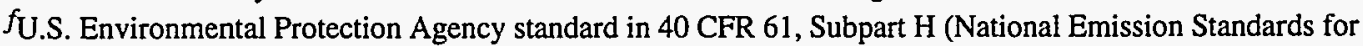
Hazardous Air Pollutants), December 1989.

$g_{\mathrm{DOE}}$ standard for the sum of all pathways in DOE Order 5400.5 .

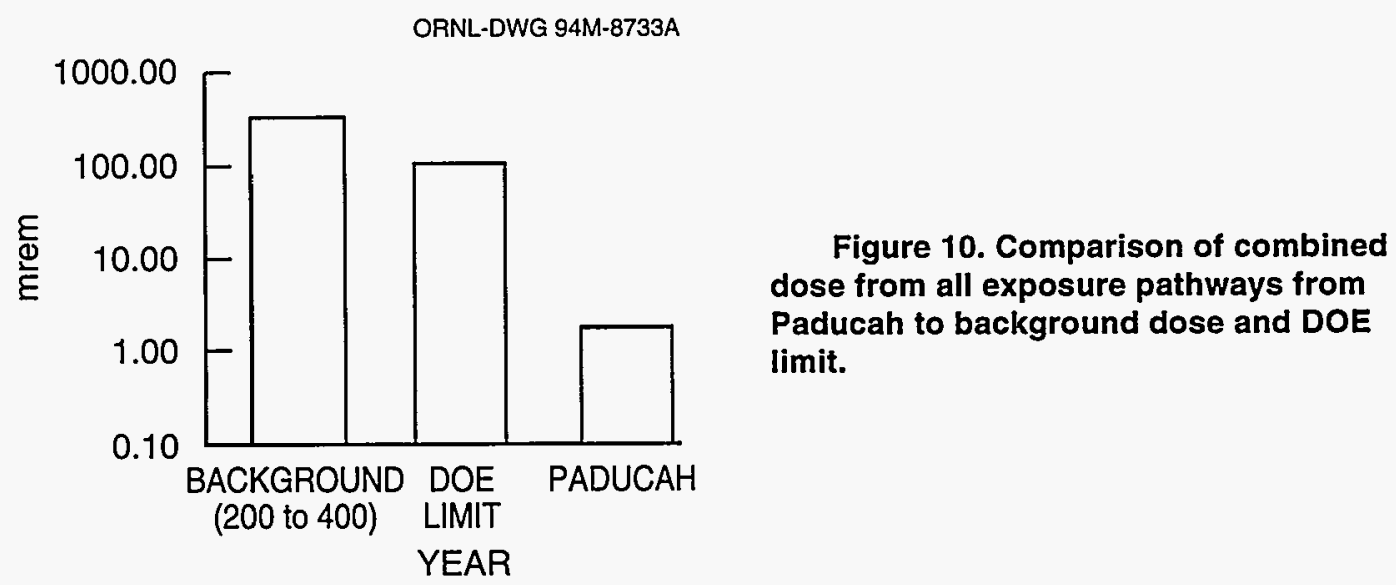




\section{PERSPECTIVE ON RADIATION AND DOSE}

Most radiation occurs naturally, and everyone is exposed to it. Naturally occurring radiation is the largest contributor to the average individual's annual dose (see Figure 11).

\section{Background Radiation}

People have no control over the amount of natural radiation around them, which stays about the same over time. In fact, the natural radiation present in the environment today is not much different than it was hundreds of years ago. Sources of natural, or background, radiation include internal radiation from food, potassium for example (everyone has approximately 500,000 atoms disintegrating in their bodies every minute); solar radiation from the sun and cosmic radiation from outside the solar system; and terrestrial radiation from the earth's rocks, soils, and minerals. Exposure to background radiation varies greatly depending on individual lifestyles, such as where a person lives and what materials were used in the building where that person lives.

ORNL-DWG 94M-9702R

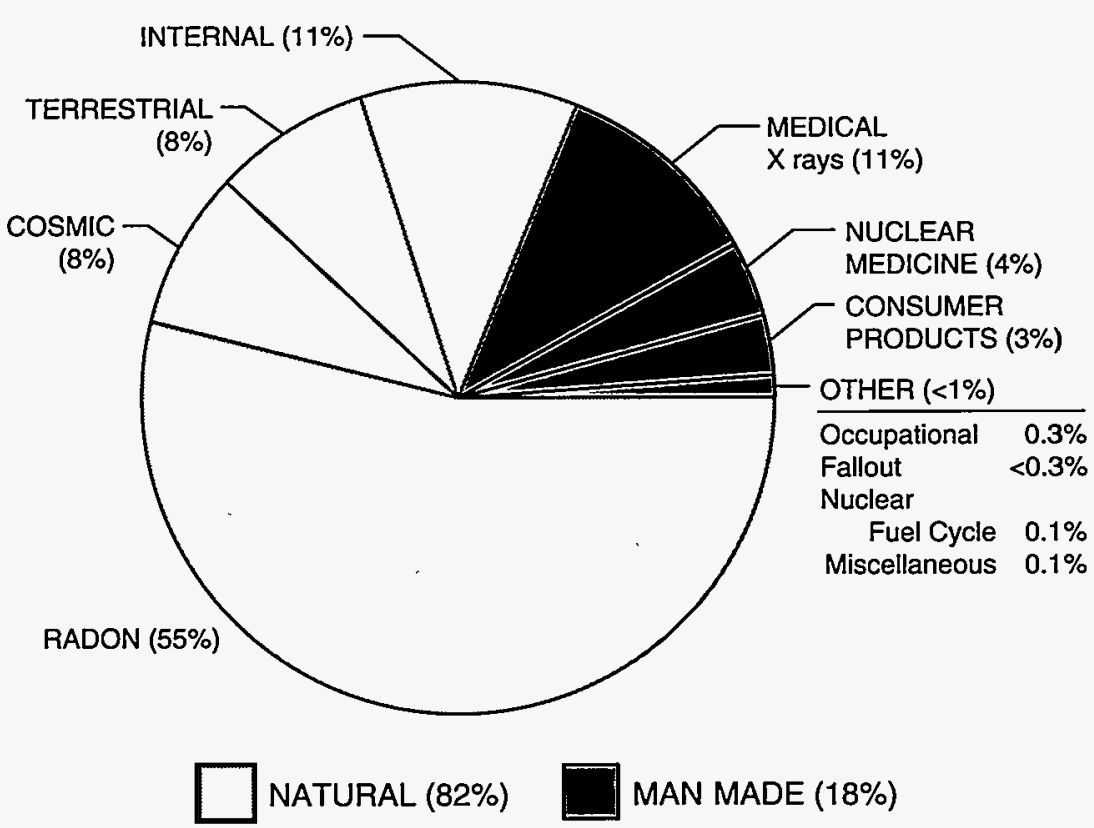

Figure 11. Sources of radiation. Radiation has always been present, and every person who has ever lived has been exposed. Although modern technology seems to have greatly increased the exposure rate, this is not necessarily the case. Exposure to human-made radiation varies greatly based on a given individual's product choices and medical treatments. In fact, exposure varies more based on where a person lives than on exposure to human-made sources. For example, the average individual in the United States receives $28 \mathrm{mrem}$ per year from radioactive elements in the soil. However, the average dose from the soil in some areas of France is 350 mrem per year. Figure redrawn with permission from the National Council on Radiation Protection and Measurements, lonizing Radiation Exposure of the Population of the United States, NCRP Report No. $93,1987$. 


\section{Human-Made Radiation}

Sources of human-made radiation include consumer products, such as color televisions, cigarettes, camera lenses, smoke detectors, and fertilizers, and medical sources, such as $\mathrm{X}$ rays, diagnostic tests, and treatments. Human-made radioactive materials also include cesium-137 and strontium-90, which are present in the environment as a result of nuclear weapons testing that was conducted in past years. As with background radiation, exposure to human-made radiation varies greatly depending on individual choices, such as smoking and eating certain food products.

\section{Comparison of Dose Levels}

The dose received by a given individual can vary widely from year to year depending on numerous factors. The average individual in the United States receives a dose from natural exposure more than 200 times greater than he or she receives from nuclear industry operations (see Table 2).

The average dose caused by background radiation also varies widely. In the United States, the average is about 300 mrem per year; however, some people in other parts of the world receive a dose more than four times this amount. For example, in some areas of Brazil the dose to inhabitants can be more than 2000 mrem per year from background radiation. These variations are caused by several factors, most notably the type and amount of radionuclides in the soil (see Figure 12).

This diversity in background radiation, not human-made radiation, is responsible for the large differences in the dose to average individuals. Because people living in areas with high levels of background radiation do so without proven harm, it is assumed by most in the scientific community that the extremely small variations in dose caused by Paducah releases have inconsequential, if any, effect on humans. See Table 3 on page 24 for a comparison of various dose levels.

Table 2. Average annual radiation dose in the United States

\begin{tabular}{|c|c|}
\hline Radiation type & Average dose \\
\hline \multicolumn{2}{|c|}{ Natural } \\
\hline Cosmic & 27 mrem \\
\hline Internal & $239 \mathrm{mrem}$ \\
\hline $\begin{array}{l}\text { Terrestrial } \\
\text { (mostly radon) }\end{array}$ & $28 \mathrm{mrem}$ \\
\hline \multicolumn{2}{|c|}{ Human made } \\
\hline Consumer products & $10 \mathrm{mrem}$ \\
\hline Medical sources & 53 mrem \\
\hline $\begin{array}{l}\text { Other (includes } \\
\text { nuclear industry) }\end{array}$ & less than $1 \mathrm{mrem}$ \\
\hline
\end{tabular}




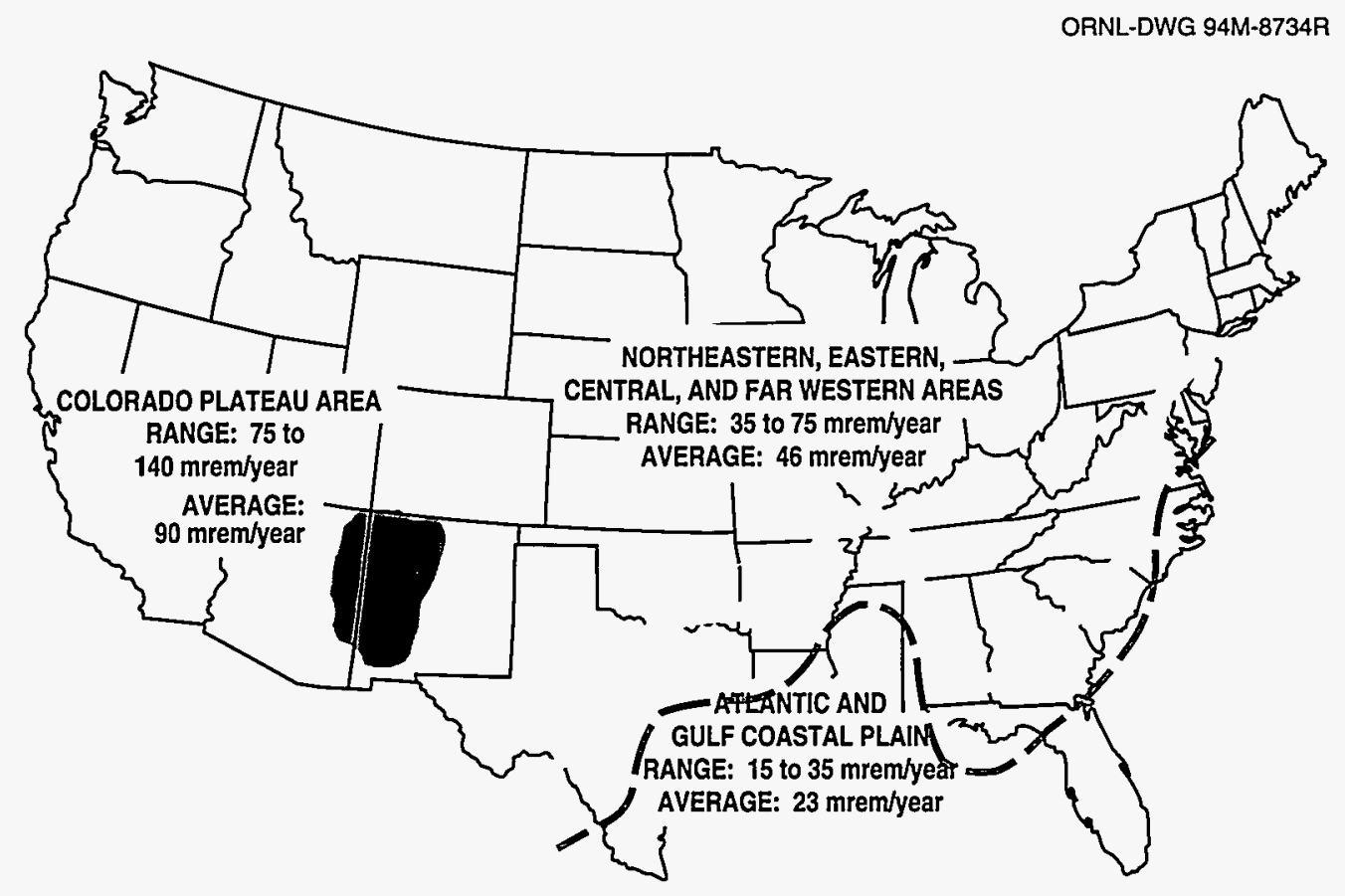

Figure 12. Average dose from terrestrial radiation in the United States. Large deposits of uranium and thorium ores in the southwest are responsible for the higher-than-average dose in the area known as the Colorado Plateau. Figure redrawn with permission from the Subcommittee on Risks of Low-Level lonizing Radiation, Low-Level Radiation Effects; A Fact Book, The Society of Nuclear Medicine, Inc., 1985. 
Table 3. Comparison and description of various dose levels

Dose level

Description

$1 \mathrm{mrem} \quad$ Approximate daily dose from natural background radiation, including radon.

$2.5 \mathrm{mrem} \quad$ Cosmic dose to a person on a one-way airplane flight from New York to Los Angeles.

10 mrem Annual exposure limit, set by the USEPA, for exposures from airborne emissions from operations of nuclear fuel cycle facilities, including power plants, uranium mines, and mills.

$45 \mathrm{mrem} \quad$ Average yearly dose from cosmic radiation received by people in the Paducah area.

$46 \mathrm{mrem} \quad$ Estimate of the largest dose any off-site person could have received from the March 28, 1979, Three Mile Island nuclear accident.

$66 \mathrm{mrem} \quad$ Average yearly dose to people in the United States from human-made sources.

100 mrem Annual limit of dose from all DOE facilities to a member of the public who is not a radiation worker.

110 mrem Average occupational dose received by U.S. commercial radiation workers in 1980 .

$244 \mathrm{mrem} \quad$ Average dose from an upper gastrointestinal diagnostic x-ray series.

$300 \mathrm{mrem} \quad$ Average yearly dose to people in the United States from all sources of natural background radiation.

1 to $5 \mathrm{rem} \quad$ Level at which USEPA Protective Action Guidelines state that public officials should take emergency action when this is a probable dose to a member of the public from a nuclear accident.

5 rem Annual limit for occupational exposure of radiation workers set by the U.S. Nuclear Regulatory Commission and DOE.

10 rem Estimated level at which an acute radiation dose would result in a lifetime excess risk of death from cancer of $0.8 \%$.

25 rem USEPA guideline for voluntary maximum dose to emergency workers for non-lifesaving work during an emergency.

$75 \mathrm{rem} \quad$ USEPA guideline for maximum dose to emergency workers volunteering for lifesaving work.

50 to 600 rem Level at which doses received over a short period of time will produce radiation sickness in varying degrees. At the lower end of this range, people are expected to recover completely, given proper medical attention. At the top of this range, most people would die within 60 days.

Adapted from Savannah River Site Environmental Report for 1993, Summary Pamphlet, WSRC-TR-94-076, Westinghouse Savannah River Company, 1994. 